\title{
Are there Slavonic features in the syntax of Romanian? Two case studies ${ }^{\dagger}$
}

\author{
Adina Dragomirescu* \\ "Iorgu Iordan - Al. Rosetti" Institute of Linguistics, Calea 13 Septembrie 13, 050711 Bucharest, Romania \\ Faculty of Letters, University of Bucharest, Str. Edgar Quinet 5-7, Sector 1, 010017 Bucharest, Romania
}

\section{Article info}

History:

Received June 10, 2014

Accepted July 8, 2014

Published January 13, 2015

Key words:

old Romanian

Romanian-Slavonic contact

relative adjectives

scrambling

auxiliary inversion

\begin{abstract}
The present paper discusses the issue of the Old Church Slavonic influence on the syntax of (old) Romanian. The starting point is the hypothesis that many of the syntactic features of Romanian previously explained by postulating the influence of (Old Church) Slavonic (especially in studies strongly influenced by ideological issues, published during the Communist period) are actually either regular transformations which occurred in the transition from Latin to Romanian, common to the other Romance languages as well, or the output of more general tendencies manifested in the history of Indo-European languages. In order to check the role of the Slavonic influence in the syntax of Romanian, we have established a working algorithm, which is applied to two phenomena from old Romanian: (i) the position of relative adjectives, and (ii) scrambling in compound verbal forms in correlation with auxiliary inversion.
\end{abstract}

\section{Introduction}

This paper investigates a controversial issue in Romanian and Romance linguistics, i.e. the existence of elements of Slav(on)ic origin in the syntax of old Romanian, eventually also transmitted to modern Romanian. The influence of Slavonic syntax on old Romanian is relevant because, as is well known, many old Romanian texts (from the $16^{\text {th }}$ century) are religious (and, to a smaller extent, legal) translations of Slavonic texts; moreover, in the relevant literature (histories of Romanian, philological studies preceding edited old texts, etc.) numerous syntactic features of old Romanian are considered to be of Slavonic origin. In the present paper, special attention is paid not to the syntactic features accidentally occurring in one old text/in a restricted number of texts but to the general features of the old language, present in many texts belonging-to the extent that this is possible-to different stylistic registers. Only two of these features (which will be accounted for in an extensive research) shall be discussed here: the position of relative adjectives and scrambling in compound verbal forms.

The subject dealt with here faces two distinct problems:

(i) a linguistic problem: is it possible for the syntax of a target language to be influenced by the source language, as it happens, obviously, in the vocabulary and in semantics? and

(ii) a historical and political problem: can the political/ideological context influence the interpretation of the data from a domain apparently independent of politics, such as linguistics?

Before analysing the linguistic data, several observations-related to the way in which history, and implicitly the oscillation of the political context, could influence the linguistic interpretation-are necessary.

${ }^{\dagger}$ This article is the revised version of the talk given at Special Romance Seminar held at University of Oxford, on February 20, 2014. I would like to thank the audience of this seminar and especially Professor Martin Maiden for comments and suggestions. I would also like to thank for comments the anonymous reviewers of the journal Diacronia.

*Email address: adina_drag@yahoo.com. 
Two opposite tendencies have manifested themselves in Romanian historiography; these tendencies have re-emerged cyclically, with each period bringing its own perspective on the past (Djuvara, 2006; Boia, 2011): on the one hand, the negation of the Slavic influence in history of Romania, especially in relation to the emergence of the Romanian language and of the Romanian population (e.g. "Școala Ardeleană" = The Transylvanian School with its exaggerated Latin "purism"), and, on the other hand, the rejection of this first tendency, manifested by claiming, in the spirit of historical objectivity, the overstatement of the role of the Slavs (e.g. the members of the "Junimea" = The Youth society, Gh. Panu, I. Bogdan, A.D. Xenopol, and "Noua S,coală" = The New School in history, represented by P.P. Panaitescu and C.C. Giurescu).

The historical jigsaw is made complete by other positions: the adoption of a moderate Slavism (B. P. Hasdeu, N. Iorga), the amplification of the Dacian influence (V. Pârvan), or the granting of a privileged role to Western European influence (T. Maiorescu, E. Lovinescu). The peak of the Slavization of the Romanian history was reached at the beginning of the Communist period (P. Constantinescu-Iași, L. Pătrăşcanu, M. Roller); at the end of the 1960s and later on, excessive nationalism cast shadow upon the Slavic component, and emphasis was thrown once more on the Dacian ingredient.

\section{The Slavic influence on the Romanian language. Previous research}

The same two opposite tendencies of historiography have operated in linguistics as well: as a reaction to the Latin purism in relation to the history of the Romanian language adopted by the Transylvanian School and its continuators, there appeared an exaggeration of the Slavic influence (at the end of the $19^{\text {th }}$ century - the beginning of the $20^{\text {th }}$ century, augmented in the early Communist period). The following issues have been emphasized: the Slavic-Romanian bilingualism (e.g. the "Daco-Slavic" language, Petrovici, 1943; see also Niculescu, 2007), the ethnic mix, including Dacian, Slavic and Latin population (Rosetti, 1968; Tagliavini, 1977), and the external Slavic influence (Cihac, 1870; Densusianu, 1961). As a reaction to Latin purism as well, the tendency to grant more weight to the influence of the Dacian language also emerged (e.g. V. Pârvan, at the beginning of the $20^{\text {th }}$ century; this idea was then strengthened, for ideological reasons, in the nationalist period of Communism).

Given these contradictory tendencies, the reality of the Slavic influence on Romanian is superficially known: on the one hand, Romanians defended their origin and national specificity (see, for similar observations related to the situation in Greece, Mackridge, 2009) but, on the other hand, they have colluded with the grand Communist ideas, overstressing the Russian/Slavic influence on the "national language" (similarly to the former Soviet countries, see Sériot, 1995).

In Romanian and Romance linguistics, there are no special studies which ascertain the consequences of the overstatement of the Slavic influence and the opposite effect, i.e. its negation, in different periods, with the exception of Zafiu (2009), which approaches the Communist period and its effects for linguistic research in general.

In the works devoted to the history of the Romanian language, there is a mild consensus on the Slavic influence in the following areas:

(i) phonology: the emergence/borrowing of the vowel $\hat{\imath}$ (cring 'little forest') and of the consonant $j$ (jale 'grief');

(ii) morphology: the preservation of two or three case forms in nominal inflection (Diaconescu, 1970, p. 198), the vocative inflexion -o (soro!), the internal structure of complex cardinal numerals from 11 unsprezece 'one-over-ten' to 19 nouăsprezece 'nine-over-ten';

(iii) syntax: the simple negation, sporadically attested in $16^{\text {th }}$ century-texts (1) (Rizescu, 1963; Ciompec, 1969; Dragomirescu, 2008), the reflexive form of many verbs (a se căi, a se griji, etc.) (Densusianu, 1961, I, p. 163; Pană Dindelegan, 2014), the dative object used instead of the direct object from modern Romanian (a crede cuiva 'believe + dative', a iubi cuiva 'love + dative') (Densusianu, 1961, I, p. 252-253; Pană Dindelegan, 2014); 
(iv) lexis: Slavic lexical influence in all domains, including the basic vocabulary (drag 'dear', a iubi 'to love', a plăti 'to pay', prieten 'friend', a primi 'to receive', scump 'dear, expensive');

(v) word formation: prefixes (ne-, răs-, prea-, etc.), suffixes (-ac, -că, -eală, -ean, etc.).

$\begin{array}{clll}\text { (1) fără de agiutoriulu celuia desusu niciu un lucru } \\ \text { without help.DEF that.GEN of up no } & \text { thing }\end{array}$ incalea vieției acestiia putemu săfacemu $\left(\mathrm{CC}_{2}, 6\right)$ in way.DEF life.DEF.GEN this.GEN can.IND.PRES.1PL S $\breve{A}_{\text {SUBJ }}$ make.SUBJ.1PL $^{\dagger}$ 'without the help of God we are not able to do a thing in this life'

Despite the general tendency to exaggerate the Slavic influence, even during Communism certain prestigious linguists rejected the Slavic determinant in the case of certain phenomena which are best accounted for by Latin facts; see, for example, Rosetti's (1968, p. 303) account for the vocative inflexion -e. A similar approach, this time with respect to syntax, is the goal of the present study.

Although in studies dedicated to the history of Romanian and in introductory studies to philological editions of old texts there are cursory references to syntactic phenomena of Slavic origin, syntax is the least investigated domain, because it is not always easy to decide which features can be accounted for only through Slavic influence, which features have another origin but have been strengthened by the Slavonic/Slavic influence, and which features have been falsely accounted for as an effect of Slavic influence for ideological reasons (related to the cultural ideology, for example, in the case of Transylvanian School, or to the political one, for example, in the case of the mystifications from the Communist period).

\section{Two case studies}

Given that the literature contains vague information and that it is often difficult to tell apart linguistic reality from false interpretation determined by ideological reasons, our research will focus on the syntactic phenomena considered to be of Slavonic/Slavic origin and will answer the following questions:

1. Which are (actually) the Romanian syntactic features that are the effect of Slavic influence and to what extent are they limited to old Romanian?

2. What algorithm of analysis can one apply to tell apart genuine syntactic features of Slav(on)ic origin from ideological overstated influence?

3. Was the Slavic influence in the syntax of Romanian overstated for the same reasons as in history?

4. Is the study of language able to provide a more accurate historical picture for other periods than the mysterious emergence of the Romanian language and people (knowing that this period was "reconstructed" mainly using linguistic data)?

\subsection{Romanian syntactic features considered to have Slavic origins}

Before going a step further with the analysis, it is necessary to give a (provisional) inventory of the syntactic phenomena which have been considered to have Slavic origins. These data are taken from books dedicated to the history of Romanian (Densusianu, 1961; Rosetti, 1968; Gheție, 1997; Ivănescu, 2000), from special studies related to the Slavic influence in the syntax of Romanian (Seidel, 1958; Beneș, 1955; Copceac, 1998) and from the linguistic studies accompanying the philologically edited texts (Mareș, 1969; Rizescu, 1971; Costinescu, 1981; Teodorescu \& Gheție, 1977; Chivu, 1993; Gheție \& Teodorescu, 2005).

\footnotetext{
${ }^{\ddagger}$ In glosses we use the following abbreviations: $\mathrm{ACC}=$ accusative, $\mathrm{AUX}=$ auxiliary, $\mathrm{CL}=$ clitic, $\mathrm{COND}=$ conditional, $\mathrm{DAT}=$ dative, $\mathrm{DEF}=$ definite, $\mathrm{DOM}=$ differential object marking, $\mathrm{F}=$ feminine, $\mathrm{FUT}=$ future, GEN $=$ genitive, GER $=$ gerund(ive), $\mathrm{IMP}=$ imperative, $\mathrm{IND}=$ indicative, $\mathrm{INF}=$ infinitive, $\mathrm{M}=$ masculine, $\mathrm{NOM}=$ nominative, $\mathrm{PERF}=$ perfective, $\mathrm{PL}=\mathrm{plural}, \mathrm{POL}=$ polite, POSS $=$ possessive, PPLE $=$ past participle, PRES $=$ present, $\mathrm{PS}=$ simple past, $\mathrm{REFL}=$ reflexive, $S \mathrm{SG}=$ singular, $\mathrm{SUBJ}=$ subjunctive. The following functional words, specific to Romanian, are also used: $A_{I N F}=$ marker of infinitive, $A L=$ freestanding syntactic marker of the genitive, $\mathrm{CEL}=$ freestanding definite determiner, $\breve{S}_{\mathrm{SUBJ}}=$ freestanding subjunctive marker.
} 
Beside the constructions mentioned above (see $\$ 2$ ), the list of the syntactic phenomena having Slavic origins also contains: the subject position and the word order of constituents within the nominal phrase, the (non-)doubling of the direct and indirect objects, differential object marking with $p e$ (< lexical $p e$ 'on'), the ellipsis of the copula a $f$ ' 'be', the predicative usage of the infinitive and of the gerund, the emergence of the "short" infinitive (without the ending -re, inherited from Latin), the usage of the infinitive in subjunctive-specific contexts, auxiliary and pronominal clitic inversion, scrambling in compound verbal forms, etc. If all these features were really imitating Slavonic constructions, then one would be able to say that the entire syntactic specificity of Romanian (especially old Romanian but also modern Romanian) is modelled on the syntax of Slavic languages.

\subsection{Working algorithm}

In order to determine in a more precise way the extension of the Slavonic/Slavic influence on the syntax of Romanian we put forth the following algorithm: if a feature occurs in at least three of the four sources indicated below, then this feature cannot be considered to have Slavic origins. The sources taken as reference points are:

(i) (late) Latin (for which we use especially the information from Ledgeway, 2012 and Adams, 2013);

(ii) other old Romance languages or dialects (we refer to Company Company, 2006 for Old Spanish, to Rohlfs, 1969, Buridant, 2000, Lardon \& Thomine, 2009 for Old French, to Salvi \& Renzi, 2010 for Old Italian, to Ledgeway, 2009 for Old Neapolitan, etc.);

(iii) old Romanian original texts (from the $16^{\text {th }}$ and the $17^{\text {th }}$ centuries, which presumably have not been heavily influenced by Slavonic);

(iv) South-Danubian dialects (these varieties have not been in contact with Slav(on)ic varieties, this phenomenon being subsequent to the dialectal split); however, we will use the dialectal data with care, since, in certain situations, it is possible that these varieties have been influenced by the modern Slavic languages with which they have been in contact; if such an influence is at play, then the dialectal data are not relevant for our algorithm.

\subsection{Case study I: the position of relative adjectives}

In contrast with modern Romanian, in which relative adjectives (such as omenesc 'human-like', dumnezeiesc 'divine', românesc 'Romanian', literar 'literary', etc.) are obligatorily postnominal, in old Romanian (up to the $19^{\text {th }}$ century) these adjectives could also occur prenominally (2); in the earliest surviving Romanian texts, the postnominal position was already more frequent (for a more detailed analysis, see Brăescu \& Dragomirescu, 2014).

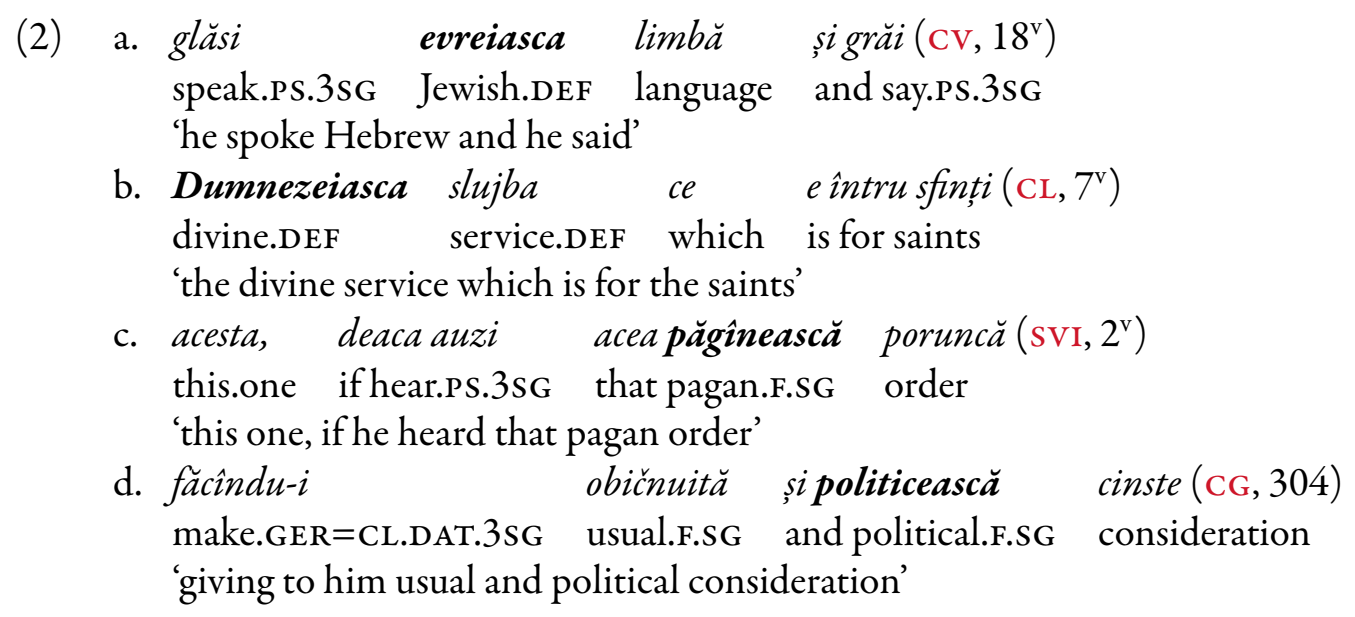

In Niculescu (1999, p. 189-196) it is shown that the postposition of the adjective with respect to the nominal head is a result of Slavonic influence. This observation is not surprising, since Old Church Slavonic also featured adjectives in prenominal position, but this position was stylistically marked (Gamanovich, 
2001, p. 315-318; Gasparov, 2001, p. 98), in contrast to old Romanian, where the ordering of the adjectives seems to be unconstrained.

Applying the algorithm described above (\$3.2), one can easily formulate the conclusion that the prenominal position of the relative adjectives can not be directly influenced by Slavonic.

(i) It is well known that in Latin adjectives had free word order (3), eventually correlated with differences in meaning. What is less clear is whether this word order variation was correlated with any information structure related/markedness differences. As Ledgeway (2012, p. 50-51) has shown, it is most probable that in Latin there were not (yet) dedicated positions for the contrastive reading of adjectives; this specialisation occurred later in the Romance varieties.

(3) a. pretor urbanus (apud Ledgeway, 2012, p. 50)

b. urbanus pretor 'magistrate for Roman citizens', 'witty magistrate'

(ii) The prenominal position of adjectives was also possible in other old Romance varieties, i.e. Old Neapolitan (4a) (Ledgeway, 2012, p. 56), Old Italian (4b) (Giusti, 2010, p. 604-605), Old French (4c) (Buridant, 2000, p. 173), etc.

(4) a. ...li spagnoli soldati (apud Ledgeway, 2012, p. 56)

'the Spanish soldiers'

b. Dice lo maestro, che la citadina maniera di dire (...) (apud Giusti, 2010, p. 604-605)

'The master says that the urban way of saying...'

c. le feminin courage

'a feminine courage'

(Jeanne Baroin et Josiane Haffen, Boccace „Des cleres et nobles femmes”, 1401)

(iii) The prenominal position of relative adjectives is also attested in old Romanian original documents:
a. svințitul
impărătescul
$\operatorname{scaun}(\mathrm{D} \hat{I}, \mathrm{XC}, \mathrm{p} .182$ )
holy.DEF.NOM royal.DEF.NOM chair
'the holy royal chair'
b. sventei dumnezeiești mănăstire (Dî, XXXIX, p. 138)
holy.DEF.DAT divine.DAT monastery
'to the holy divine monastery'
c. Şiaceasta impreună cu celelalte delingăea
and this together with the.other.PL of next her

\begin{tabular}{|c|c|c|c|c|}
\hline ste & & domneștii & și dumnezeieştii & mănăstiri \\
\hline & AL.F.SG & princely.F.SG.DEF.GEN & and divine.F.SG.DEF.GEN & monastery.GEN \\
\hline & celor & Trei Ierarbi & CM, p. 255) & \\
\hline & G CEL. & M.PL.GEN Three Hiera & from Iași & \\
\hline
\end{tabular}

'And this, together with the others next to it, belongs to the holy monastery Three Hierarchs from Iași'

(iv) In the South-Danubian varieties, the position of the relative adjectives is also free (Martin Maiden, p.c.). Zegrean (2012, p. 91-92) has noticed that, in Istro-Romanian, most probably under the influence of Croatian, the unmarked order of the adjectives, including relative adjectives, is prenominal (6); she has also identified the conditions for the postnominal positions. In Megleno-Romanian as well (Atanasov, 1984, p. 536-537) the adjective is ordered prenominally, probably as a result of Macedonian influence; the postnominal position is also frequent.

(6) Io cunosc ur taljanski fečor (apud Zegrean, 2012, p. 93)

I know.1sg an Italian boy

'I know an Italian boy'. 


\subsection{Case study II: scrambling in compound verbal forms and auxiliary inversion}

In this section two apparently independent syntactic phenomena, which set apart old Romanian from modern Romanian, are presented together: scrambling and auxiliary inversion (see, for details Dragomirescu, 2013 and 2014, where it is shown that the syntactic analysis of the two phenomena is unitary and a unique parametric change can account for the changes related to these phenomena).

In modern Romanian, scrambling in compound verbal forms is only possible with adverbial clitics (known in the Romanian literature as "semiadverbs" - (7)), while in old Romanian scrambling was much more extended (8), with phrasal constituents displacing the verbal elements of the verbal cluster.

a. $A m$ cam greșit.

AUX.PERF.1SG rather be.wrong.PPLE

'I was rather wrong'

b. Vor mai cîştiga.

AUX.FUT.3PL again win.INF

'They will win again'
a. de rroada
voiu
pîntecelui
tău punre
of fruit.DEF
AUX.FUT.1 SG
belly.DEF.GEN
your put.INF
pre scaunul tău $\left(\mathrm{PH}, 113^{\mathrm{v}}\right)$
on chair.DEF your.POSS
'I will put on your chair one of your children'
b. bogătatea se ară pre aproape
curre,
richness.DEF if AUX.COND.3SG on near.by flow.INF
nu punereți
innima $\left(\mathrm{PH}, 51^{\mathrm{v}}\right)$
not put.IMP.2sG heart.DEF
'If the richness flows near by, do not pay attention to it'
tatăl tău

tremis $\left(\mathrm{CM}, 240^{\mathrm{v}}\right)$

but CL.ACC.2SG=AUX.PERF.3SG father.DEF your send.PPLE 'but your father has sent you'

d. deva grăunțulde grîu cădea la pămînt if AUX.FUT.3sG seed.DEF of wheat fall.INF on ground

sinu va muri $\left(\mathrm{CC}_{1}, 116^{\mathrm{v}}\right)$

and not AUX.FUT.3sg die.INF

'if the wheat seed falls on ground and does not die'

e. necesăară cineva den morți invie $\left(\mathrm{CC}_{1}, 120^{\mathrm{v}}\right)$

nor if AUX.COND.3sG someone from deaths raise.INF 'nor if someone raised from the dead'

f. Sicînd featele aceaste îndărăptu se inturnară

and when girls.DEF these back CL.REFL come.PS.3sG

la tatăl său, dzise tată-său: cum ați

at father.DEF their.POSS say.PS.3SG father=their.POSS how AUX.PERF.2PL

astădzi aşacurund venit acasă? (PO, 184)

today so soon come.pPLE home

'And when the girls came back to their father, their father said: how could you come back home so soon?'

g. cîndva omul să imble pre toatevoile $\left(\mathrm{FD}, 593^{\mathrm{v}}\right)$

when AUX.FUT.3SG man.DEF S $\breve{A}_{\text {SUBJ }}$ go on all whishes

'when the man will go as much as he whishes'

As for auxiliary inversion, in the present-day language it is strictly limited to imprecations, in the spoken language (9a), to direct questions, in certain dialectal areas (9b), and to religious speech, where it is an 
archaic feature (9c). In old Romanian, auxiliary inversion seems to be a free phenomenon (10) (which is however preferred in main clauses, especially in initial position, see Zafiu, 2014).

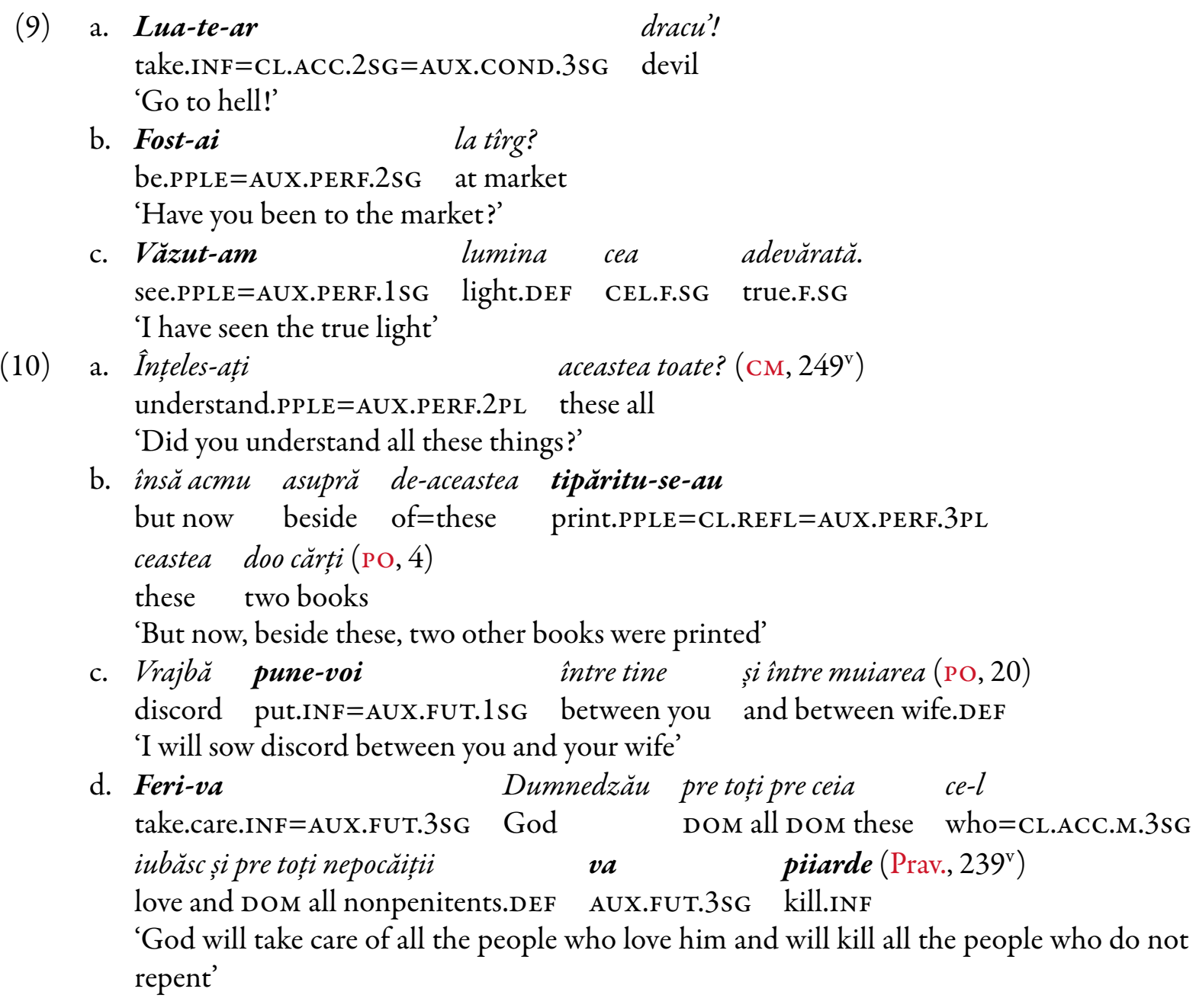

In previous research regarding scrambling and/or auxiliary inversion (Moldovanu, 1977-1978; Gheție \& Zgraon, 1981; Zamfir, 2007; Frâncu, 2009), it is shown that this atypical word order is determined either by the preservation of an archaic syntactic rule, which was probably general in Romanian before the first attested texts (see Moldovanu, 1977-1978), or represents the result of the Slavonic influence, by means of translations. The second explanation is supported by the existence of auxiliary inversion in Old Church Slavonic (11); unfortunately, we did not find any relevant information in the literature with respect to scrambling in Old Church Slavonic.

(11) ne srdoe li naju gore $e_{\mathrm{part}} \boldsymbol{b}_{\mathrm{eux}}$ vbı naju

'Were not our hearts burning within?' (Lk, 24, 32, apud Pancheva, 2008)

Nevertheless, the application of the algorithm described in $\$ 3.2$ leads to the conclusion that Slavonic influence is not a satisfactory explanation for the phenomena investigated here.

(i) It is known (Thielmann, 1885; Bauer, 2006; Adams, 2013) that in Latin the structures of the type habeo + object + past participle are attested since the archaic period, but, as extremely convincingly shown by Adams (2013, p. 646, passim), habeo was not an auxiliary, and, consequently, it did not have word order and adjacency constraints. For other forms containing an auxiliary, Latin is irrelevant, since periphrastic forms grammaticalized later in Romance, and implicitly in Romanian. The unmarked order of the habeo-structures in Latin was past participle + habeo ((12) - see Bauer, 2006, p. 293; Adams, 2013, p. 648). The possibility to insert different constituents, especially the direct 
object, between the past participle and habeo is largely attested in Latin (see Bauer, 2006, p. 293; Adams, 2013, p. 649).
omnes scaphas
ad litus appulsas pple $_{\text {. }}$
habeant $_{\text {aux }}$

all.ACC boats.ACC to coast bring.to.land.PPLE.ACC.PL have.SUBJ.3PL

'(that) they have all boats brought to land' (Cæs., DBL.2.43.1, apud Bauer, 2006, p. 295)

(ii) In numerous old Romance varieties scrambling is permitted: Old Spanish (13a-b), Old Italian (13cd), Old French (13e-f), etc.

(13) a. Porque elle non avia las cartas resçebidas (apud Mensching, 2012, p. 22)

'Because she had not received the letters'

b. Eran sos fijos idos al canpo (apud Company Company, 2006, p. 328)

'His sons were gone in the field'

c. avrebbono a Alessandro e forse alla donna fatta villania (apud Mensching, 2012, p. 22) 'the would have affronted Alessandro and perhaps the lady, too'

d. Quali denari avea Baldovino lasciati loro (apud Poletto, 2006) 'Which money Baldovino had left them'

e. pour la grant amour ai je pourchacié (apud Sitaridou, 2012, p. 588) 'For the great love, I have pursued'

f. Un pou aprés eure de prime fu Mador venuz (apud Mensching, 2012, p. 32)

'And shortly after the first hour Mador had arrived'

Moreover, numerous old Romance varieties permit auxiliary inversion: Old Spanish (14a-c), Old Italian (14d), Old French (14e-f), etc.

(14) a. Fecho as tú otro tal a los otros (apud Mensching, 2012, p. 22)

'You have done the same to the other ones'

b. passada han la sierra (apud Company Company, 2006, p. 292) 'they crossed the mountain'

c. cogida han la tienda (apud Company Company, 2006, p. 292) 'they pulled down the tent'

d. almeno quello che detto è _ non è inutile a sapere (apud Poletto, 2014) 'At least what is said isn't useless to know'

e. por pooir que nos aïons, recovree ne sera, se par ceste genz non (apud Frappier, 1976, p. 80) 'no matter how poor we are, [the fortress] will not be conquest, at least not by these people'

f. Le voir reconeü vos ai (apud Buridant, 2000, p. 377)

'I have confessed the truth to you'

Similarly to Romanian (which lost scrambling and auxiliary inversion towards the end of the old period, conventionally delimited by the year 1780), the other Romance languages lost the scrambling option and the order participle-auxiliary as the unmarked word order at a certain point, most probably, in the $15^{\text {th }}$ century in Spanish (Company Company, 2006, p. 287-299, 325-328) and in the $16^{\text {th }}$ century in Italian (Poletto, 2006).

(iii) Both scrambling (15) and auxiliary inversion (16) are attested not only in translations but also in Romanian original documents:

a. Iar de-ai

bi domiata sîrguit să fiipînă acmu

venit, and if=AUX.COND.3SG be you.POL strive.PPLE S $\breve{A}_{\text {SUBJ }}$ be until now come.PPLE avem nădeajde preDumnedzeu să fifost have.IND.PRES.1PL hope in God S $\breve{A}_{\text {SUBJ }}$ be be.PPLE 
pînă acmu și la moșie. (Dî̀, XCIII, p. 184)

until now and at estate

'And if your highness had strived to have arrived by now, we hope in God, you would have been at estate until now'

b. Deva veni birdeni, vor Nicorizi Nevrudul

if AUX.FUt.3Sg come.INF Birdeni AUX.Fut.3sg Nicorizi Nevrudul

a čeri čevaban (Dî, CI, p. 193)

$\mathrm{A}_{\mathrm{INF}}$ ask.INF some money

'If Birdeni comes, Nicorizi Nevrudul will ask for some money'

c. aceaea care-ară $f i$ innapoi rămas (Dî, XXXVI, p. 125)

that.F.SG who $=$ AUX.COND.3SG be.INF behind remain.PPLE

'the one that would have remained behind'

(16)

a. Pusu-ne-am

și degetele mai jos (Dî, VI, p. 99)

put.PPLE $=$ CL.REFL.ACC. $1 \mathrm{PL}=$ AUX.PERF.1PL and fingers more down

'We have put our fingers below'

b. cum veri zice, sta-vor au

how AUX.FUT.2SG say.INF stay.INF=AUX.FUT.3PL or

mearge-vor (Dî,, XXXII, p. 127)

go.INF=AUX.FUT.3PL

'as you will say, they will stay or they will go'

c. Acestesfinte cărți ce se cheamă Minice

these holy books which CL.REFL call.InD.PRES.3PL Miniæ

datu-le-au Antiobie Jora (ITM, p. 362)

give.PPLE $=$ CL.ACC.F.3SG $=$ AUX.PERF.3SG Antiohie Jora

'These holy books called Miniæ were given by Antiohie Jora'

(iv) As for the South-Danubian varieties of Romanian, we only found relevant data for Istro-Romanian and Megleno-Romanian. In Istro-Romanian, scrambling is still possible (17), and postverbal placement of the auxiliary in the perfect and the future tenses is a frequent phenomenon (18) (Sandfeld, 1930, p. 149; Caragiu Marioțeanu, 1975, p. 205; Caragiu Marioțeanu et al., 1975, p. 225; Kovaček, 1984, p. 576; Zegrean, 2012).

a. Mâre vo tomorrow AUX.FUT.1sG I kill.INF

'Tomorrow I'll kill'

b. An cârca cu bręnta am apa purtat in back with bucket.DEF AUX.PERF.1sG water.DEF brought.PPLE 'I carried the water on my back with the bucket' (apud Zegrean, 2012, taken from Sârbu, 1992)

c. Ier-am mušat cantat (apud Zegrean, 2012) yesterday=AUX.PERF.1sG beautifully sing.PPLE 'Yesterday I sang beautifully'
a. Ier
citeit-nu-am
nič (apud Zegrean, 2012)
yesterday read.PPLE $=$ not $=$ AUX.PERF.1SG nothing
'I didn't read anything yesterday'

b. Datu-mi-a regalu, ne boca devir give.PPLE $=$ CL.DAT.1SG=AUX.PERF.3SG gift.DEF not bottle.DEF of wine '(S)he gave me the gift, not the bottle of wine' (apud Zegrean, 2012)

In Megleno-Romanian, the past auxiliary is also frequently postverbal in certain varieties (19) (see Sandfeld, 1930, p. 149; Caragiu Marioțeanu, 1975, p. 282; Caragiu Marioțeanu et al., 1975, p. 207; Atanasov, 
1984, p. 523-527); the future has only synthetic forms, and thus it is not relevant for the phenomenon investigated here. Atanasov (1984, p. 527) shows that the participle + auxiliary ordering is used in MeglenoRomanian when speakers report an event to which they did not take part (see 19c-d, where the context is larger), in other words auxiliary inversion marks evidentiality. This is also the case in Macedonian, a Slavic language that might have influenced Megleno-Romanian; if Megleno-Romanian was indeed influenced by Macedonia, then the data from this dialect are not relevant for our demonstration.
a. rugat-åm (apud Caragiu Marioțeanu et al., 1975, p. 225) asked $=$ AUX.PERF.1SG
'I have asked'
b. țirút-ai (apud Caragiu Marioțeanu et al., 1975, p. 225) asked $=$ AUX.PERF.2SG
'You have asked'
c. ier fóst-ăi yesterday be.PPLE=AUX.PERF.2SG at work
'I have heard that you have been to work yesterday'
d. țiruit-ău si vină la noi want.PPLE=AUX.PERF.3PL SĂ $\breve{S U B J}_{\text {SU }}$ come.SUBJ.3PL at us 'I have heard that they wanted to come to our place' (apud Atanasov, 1984, p. 527)

\section{Conclusions}

In this final section we try to answer, at least partially, the questions raised at the beginning of $\$ 3$.

The data briefly presented here show that, before considering that a syntactic feature (of Romanian) is the outcome of a foreign language influence (Slav(on)ic), one should take into account other possible scenarios, which can prove more appropriate. For (Daco-)Romanian, it is without doubt that the Latin heritage, the comparison with other old Romance languages, and the comparison with the SouthDanubian varieties can be more useful than the claim-more often not supported by data and influenced by ideological considerations - that certain phenomena are due to Old Church Slavonic influence.

The algorithm we have put forth and applied to two phenomena considered in the literature to have Slavonic origins, rather explained as tendencies common to the Romance languages (eventually subordinated to certain general tendencies of the Indo-European languages, hence the similarities with Old Church Slavonic and with modern Slavic languages) can be applied to the entire list of phenomena presented in section $\$ 3.1$, possibly augmented with other syntactic data.

If this algorithm is not entirely satisfactory, one can also resort to a syntactic formal analysis which, independently of the data from Latin or other Romance languages, explains the diachronic differences; for example, one can invoke the generative concept parametric change (where parameter means a formal feature of a functional category, while parametric change is related to the distribution of features, which, in diachrony, can be subject to certain transformations-Roberts, 2012). In this framework, the obligatorily postnominal position of relative adjectives from modern Romanian is the result of a parametric change taking place in Romanian: the loss of a specific type of movement (phrasal movement, precisely $A$ (djectival)P(hrase)-movement) in the nominal domain (see, for details, Brăescu \& Dragomirescu, 2014). In a similar manner, the loss of scrambling and auxiliary inversion can be accounted for by a unique parametric change: the loss of a feature responsible for movement in the Complementizer domaincorrelated with the loss of auxiliary inversion-and in the little $v$ domain (responsible for licensing Accusative case) - correlated with the loss of scrambling (see, for details and references, Dragomirescu, 2013 and 2014).

Applying this algorithm and finding formal explanations for the phenomena inventoried under $\$ 3.1$ will allow us to give a more coherent description of the syntactic features of (old) Romanian, in relation 
to Latin and Romance languages, on the one hand, and with Old Church Slavonic and modern Slavic languages, on the other hand. The expected result of this research is undoubtedly a list of syntactic features borrowed form Slavonic much more limited than it is actually shown in the existing literature.

Coming back to the grounds which determined the overstatement of the Slavonic/Slavic influence in the Romanian syntax, one can claim that the reasons for "falsification" are mainly ideological, but one can also add the lack - up until recently — of the relevant syntactic information about (Late) Latin, Romance languages (especially their old stages), and even about the South-Danubian varieties, as well as the perpetuation, without checking, of information from works which have been ideologically corrupt.

While the role of ideology in the mystification and the interpretation of certain linguistic data in its own benefit is clear enough, the opposite direction is less evident: to a certain extent, the linguistic data as well (controversial or obviously falsified) have been used to support certain historical mystifications, related not only to the old history (the emergence of the Romanian language and people, more or less subject to the Slavic influence, depending on the ideological necessities of the moment) but also to the more recent history (in the Communist period, the Slavic influence has been highlighted and exaggerated not only in linguistics but also in other domains).

\section{Bibliography}

\section{A. Corpora}

$\mathrm{CC}_{1}=$ Coresi, Tîlcul evangheliilor, in Coresi, Tîlcul evangheliilor și molitvenic românesc (1567-1568), ed. V. Drimba, Editura Academiei Române, București, 1998, p. 31-187.

$\mathrm{CC}_{2}=$ Coresi, Carte cu invaățătură (1581), ed. S. Pușcariu, Al. Procopovici, Atelierele Grafice Socec \& Co., București, 1914.

$\mathrm{CG}=$ Literatura românescă de ceremonial. Condica lui Gheorgachi (1762), ed. Dan Simonescu, Fundația Regele Carol I, București, 1939.

$\mathrm{CL}=$ Coresi, Liturghier (1570), ed. Al. Mareș, Editura Academiei, București, 1969.

$\mathrm{CM}=$ Coresi, Molitvenic, in Coresi, Tülcul evangheliilor și molitvenic românesc (1567-1568), ed. V. Drimba, Editura Academiei

Române, București, 1998, p. 189-211.

$\mathrm{Cv}=$ Codicele Voronețean (1563-1583), ed. M. Costinescu, Editura Academiei, București, 1981.

Dî = Documente și însemnări româneşti din secolul al XVI-lea, ed. Gh. Chivu, M. Georgescu, M. Ioniță, Al. Mareș, A. RomanMoraru, Editura Academiei, București, 1979.

FD = Floarea darurilor (1592-1604), ed. A. Roman Moraru, Minerva, București, 1996 (Cele mai vechi cărți populare, I), p. $119-182$.

ITM = Însemnări pe de pe manuscrise și cărțti vechi din Țara Moldovei, un corpus editat de I. Caproșu și E. Chiaburu, Demiurg,

Iaşi, 2008, vol. I, (1429-1750), p. 130-582.

PH = Psaltirea Hurmuzaki (1500-1510), ed. I. Gheție și M. Teodorescu, Editura Academiei Române, București, 2005.

Po = Palia de la Orăștie (1582), ed. V. Pamfil, Editura Academiei, București, 1968.

Prav. $=$ Pravila ritorului Lucaci (1581), ed. I. Rizescu, Editura Academiei, București, 1971.

svi = Varlaam și Ioasaf (1670), ed.: M. Stanciu Istrate, Reflexe ale medievalității europene în cultura română veche: Varlaam și

Ioasaf în cea mai veche versiune a traducerii lui Udriște Năsturel, Editura Muzeului Național al Literaturii Române, București, 2013.

\section{B. References}

Adams, J. (2013). Social Variation and the Latin Language, Cambridge University Press, Cambridge, CrossRef.

Atanasov, P. (1984). Meglenoromâna, in: V. Rusu (ed.), Tratat de dialectologie românească, Scrisul Românesc, Craiova, p. $476-$ 550.

Bauer, B.L.M. (2006). 'Synthetic' vs. 'analytic' in Romance. The importance of varieties, in: R. Gess, D. Arteaga (eds), Historical Romance Linguistics. Retrospective and Perspectives, Benjamins, Amsterdam, p. 287-304.

Beneș, P. (1955). Inncrucișarea slavo-română în forma infinitivului românesc, in „Studii și cercetări lingvistice”, VI, 3-4, p. 255 263.

Boia, L. (2011). Istorie și mit în conștiința românească, $3^{\text {rd }}$ ed., Humanitas, București.

Brăescu, R. \& Dragomirescu, A. (2014). Sintaxa adjectivelor relaționale in limba română veche, in „Limba română”, LXIII, 1, p. 27-47.

Buridant, C. (2000). Grammaire nouvelle de l'ancien français, SEDES, Paris.

Caragiu Marioțeanu, M. (1975). Compendiu de dialectologie română (nord- și sud-dunăreană), Editura Științifică și Enciclopedică, București. 
Caragiu Marioțeanu, M., Giosu, Ș., Ionescu-Ruxăndoiu, L. \& Todoran, R. (1977). Dialectologie română, Editura Didactică și Pedagogică, București.

Chivu, G. (1993). Studiu lingvistic, in Codex Sturdzanus, Editura Academiei Române, București, p. 142-230.

Cihac, Al. (1870). Dictionnaire d'étymologie daco-romane, Francfurt am Main/Berlin/Bucarest.

Ciompec, G. (1969), Observații asupra exprimării negației în limba română din secolele al XVI-lea - al XVIII-lea, in „Studii și cercetări lingvistice", XX, 2, p. 197-209.

Company Company, C. (ed.). (2006). Sintaxis histórica de la lengua española, FCE, UNAM, Mexico.

Copceac, D. (1998). Paralele slavo-române in sintaxa prepozițiilor, in Tipologia limbilor romanice, $2^{\text {nd }}$ ed., Clusium, Cluj, p. $198-229$.

Costinescu, M. (1981). Studiu lingvistic, in Codicele Voronețean, Editura Minerva, București, p. 89-213.

Densusianu, O. (1961). Istoria limbii române I, II, Editura Științifică, București.

Diaconescu, P. (1970). Structură și evoluție în morfologia substantivului românesc, Editura Academiei, București.

Djuvara, N. (2006). Există istorie adevărată? Despre „relativitatea generală” a istoriei. Eseu despre epistemologie, $2^{\text {nd }} \mathrm{ed} ., \mathrm{Hu}^{-}$ manitas, București.

Dragomirescu, A. (2008). Concordanța negației în limba română veche, in G. Pană Dindelegan (ed.), Limba română. Dinamica limbii, dinamica interpretării, Editura Universității din București, p. 219-226.

Dragomirescu, A. (2013). O schimbare parametrică de la româna veche la româna modernă în sintaxa formelor verbale compuse cu auxiliar, in „Limba română”, LXII, 2, p. 225-239.

Dragomirescu, A. (2014). The syntax of compound tenses and scrambling in old Romanian, talk given at SyntaxLab, University of Cambridge, Cambridge, February 11, 2014.

Frappier, J. (1976). Le style de Villehardouin dans les discours de sa chronique, in: Histoire, mythes et symbols. Études de literature française, Librairie Droz, Genève, p. 73-83.

Frâncu, C. (2009). Gramatica limbii române vechi (1581-1780), Casa Editorială Demiurg, Iași.

Gamanovich, (Archbishop Alypy). (2001). Grammar of the Church Slavonic language, English edition translated from Russian, Holy Trinity Monastery, Jordanville, New York.

Gasparov, B. (2001). Old Church Slavonic, LICOM Europa, Munchen.

Gheție, I. (coord.) (1997). Istoria limbii române literare. Epoca veche (1532-1780), Editura Academiei Române, București.

Gheție, I. \& Zgraon, F. (1981). Despre așa-numitele formații premorfologice din limba română veche, in „Studii și cercetări lingvistice", XXXII, 2, p. 179-181.

Gheție, I. \& Teodorescu, M. (2005). Studiu lingvistic, in Psaltirea Hurmuzaki I, Editura Academiei Române, București, p. 23-83.

Giusti, G. (2010). Il sintagma aggetivale, in: G. Salvi, L. Renzi (eds), Grammatica dellitaliano antico, Il Mulino, Bologna, p. 593-616.

Ivănescu, G. (2000). Istoria limbii române, $2^{\text {nd }}$ ed., Editura Junimea, Iași.

Kovaček, A. (1984). Istroromâna, in: V. Rusu (ed.), Tratat de dialectologie românească, Scrisul Românesc, Craiova, p. 550-590.

Lardon, S. \& Thomine, M.-C. (2009). Grammaire du français de la Renaissance. Étude morphosyntaxique, Editions Classiques Garnier, Paris.

Ledgeway, A. (2009). Grammatica diacronica del dialetto napoletano, Max Niemeyer Verlag, Tübingen, CrossRef.

Ledgeway, A. (2012). From Latin to Romance. Morphosyntactic Typology and Change, Oxford University Press, Oxford, CrossRef.

Mackridge, P. (2009). Language and National Identity in Greece 1766-1976, Oxford University Press, Oxford/New York, CrossRef.

Mareș, Al. (1969). Studiu de limbă, in Liturghierul lui Coresi, Editura Academiei, București, p. 47-118.

Mensching, G. (2012). Parameters in Old Romance word order, in: C. Galves, S. Cyrino, R. Lopes, F. Sandalo, and J. Avelar (eds.), Parameter Theory and Linguistic Change, Oxford University Press, Oxford, p. 21-42.

Moldovanu, D. (1977-1978). Formațiile premorfologice din limba română veche, in „Anuarul de lingvistică și istorie literară”, XXVI, p. 45-69.

Niculescu, Al. (1999). Individualitatea limbii române între limbile romanice, vol. 3, Clusium, Cluj-Napoca.

Niculescu, Al. (2007). Románia slavica, in L'altra latinità. Storia linguistica del romeno tra Oriente e Occidente, Edizioni Fiorini, Verona, p. 95-104.

Pană Dindelegan, G. (2014). Variație în construcția verbului în limba veche, in R. Zafiu, A. Dragomirescu, A. Nicolae (eds.), Diacronie și sincronie în studiul limbii române, vol. I, Editura Universității din București, București (sub tipar).

Pancheva, R. (2008). Head-Directionality of TP in Old Church Slavonic, in: A. Antonenko, J. F. Bailyn, C. Y. Bethin (eds), Annual Workshop on Formal Approaches to Slavic Languages. The Stony Brook Meeting 2007, Michigan Slavic Publications, Ann Arbor, p. 313-332.

Petrovici, E. (1943). Daco-slava, in „Dacoromania”, X, II, p. 233-277.

Poletto, C. (2006). Parallel phases: a study on the hight and low left periphery of Old Italian, in: M. Frascarelli (ed.), Studies in Generative Grammar, Mouton de Gruyter, Berlin, p. 261-294.

Poletto, C. (2014). Word order in Old Italian, Oxford University Press, Oxford, CrossRef. 
Rizescu, I. (1963). Cu privire la dubla negație in limba română, in „Studii și cercetări lingvistice”, XIV, 4, p. 471-478.

Rizescu, I. (1971). Studiu de limbă, în Pravila ritorului Lucaci, Editura Academiei, București, p. 35-145.

Roberts, I. (2012). Macroparameters and Minimalism, in: C. Galves, S. Cyrino, R. Lopes, F. Sandalo, and J. Avelar (eds), Parameter Theory and Linguistic Change, Oxford University Press, Oxford, p. 320-335.

Rohlfs, G. (1969). Grammatica storica della lingua italiana et dei suoi dialetti, vol. III, Sintassi e formazione delle parole, Turin.

Rosetti, Al. (1968). Istoria limbii române de la origini pinnă în secolul al XVII-lea, Editura pentru Literatură, București.

Salvi, G. \& Renzi, L. (eds). (2010). Grammatica dellitialiano antico, Il Mulino, Bologna.

Sandfeld, Kr. (1930). Linguistique balkanique. Problèmes et resultants, Champion, Paris.

Sârbu, R. (1992). Texte istroromâne cu un studiu introductiv "Istroromâna - azi” și un glosar, $2^{\text {nd }}$ ed., Editura Universității din Timișoara, Timișoara.

Seidel, E. (1958). Elemente sintactice slave în limba română, Editura Academiei, Bucureşti.

Sériot, P. (1995). Changements de paradigmes dans la linguistique soviétique des années 1920-1930, în Histoire epistémologie langage, XVII, 2, p. 235-251.

Sitaridou, I. (2012). A comparative study of word order in Old Romance, in „Folia linguistica”, 46, 2, p. 553-604, CrossRef.

Tagliavini, C. (1977). Originile limbilor neolatine - introducere in fiologia romanică, $2^{\text {nd }}$ ed., Editura Științifică și Enciclopedică, București.

Teodorescu, M. \& Gheție, I. (1977). Studiu de limbă, in Manuscrisul de la Ieud, Editura Academiei, București, p. 59-141.

Thielmann, Ph. (1885). Habere mit dem Infinitiv und die Entstehung des romanischen Futurums, in „Archiv für lateinische Lexicographie und Grammatik", 2, 372-423, 509-549.

Zafiu, R. (2009). Ideologie și mit in lingvistica românească, in „Communication interculturelle et littérature”, 2, 6, p. 313-324.

Zafiu, R. (2014). Auxiliary encliticization in 16th century Romanian: restrictions and regularities, în „Linguistica Atlantica”, 33, 2, p. 71-86.

Zamfir, D.-M. (2007). Morfologia verbului in dacoromâna veche (secolele al XVI-lea - al XVII-lea), Partea a II-a, Timpurile din sfera trecutului. Viitorul. Condiționalul, Editura Academiei Române, București.

Zegrean, I.-G. (2012). Balkan Romance: Aspects of the Syntax of Istro-Romanian, PhD Thesis, Università Ca'Foscari Venezia. 